\title{
Diversity and violence during conflict migration: The Troubles In Northern Ireland*
}

\author{
Claire L. Adida Joseph Brown Gordon C. McCord \\ Paul McLachlan
}

May 13, 2021

${ }^{*}$ Claire Adida is Associate Professor of Political Science, UC San Diego, 9500 Gilman Drive, La Jolla, CA 92037, USA (cadida@ucsd.edu). Joseph M. Brown is Assistant Professor of Political Science, University of Massachusetts Boston, 100 Morrissey Boulevard, Boston, MA 02125, USA (joseph.brown@umb.edu). Gordon C. McCord is Associate Professor of Economics at the School of Global Policy and Strategy, UC San Diego, 9500 Gilman Drive, La Jolla, CA 92037. Paul McLachland is an independent scholar, 2755 Augustine Drive, Santa Clara, CA 95054 (pmclachlansf@gmail.com). Authors' names listed in alphabetical order. Please direct correspondence to Joseph Brown (joseph.brown@umb.edu). We are indebted to Andrea de Barros and Máirelise Robinson for excellent research assistance. 


\begin{abstract}
The effect of diversity on violence is ambiguous. Some studies find that diverse areas experience more violence; others find the opposite. Yet violence displaces and intimidates people, creating measurement challenges. We propose a novel indicator of diversity that circumvents these problems: the location of physical structures at disaggregated geographical levels, and introduce this solution in the context of the Troubles in Northern Ireland. Our data reveals a curvilinear relationship between diversity and violence with the steepest increase at low diversity, driven by an increase in violence when our proxy for Catholic proportion of the population rises from 0 to $20 \%$. These patterns are consistent with a theory of group threat through exposure.
\end{abstract}




\section{Introduction}

Conflict between Catholics and Protestants in Northern Ireland dates back to the settlement of the Plantation of Ulster in 1609. In the late 1960s, however, the violence escalated to unprecedented levels, leaving approximately 3,500 people dead of which half were civilians and $7 \%$ were children. This 30-year conflict, commonly referred to as the Troubles, has been described as "one of the 20th century's most violent and enduring sectarian conflicts" (Gladstone and Robins 2021).

Expert analyses of violence in Belfast, where the majority of deaths from the Troubles occurred, document two distinct phenomena: during this period of instability, violence occurred both where Protestants and Catholics interfaced and within their enclaves. Indeed, before the explosion of the Troubles, Catholics and Protestants in Belfast had organized their lives through a dual geographic arrangement: the sanctuary/interface complex. This spatial organization combined both an ethnically homogeneous enclave space where everyday life took place, and a frontlines space where ideological and ethnic contestation occurred (Feldman 1991). And yet, in the evolution of the Troubles throughout the early 1970s, these enclaves turned deadly; paramilitaries converted them into operational bases and once-safe spaces became loci of violence (Feldman 1991). In other words, the enclaves offered both a safe space and a safe haven from which to organize attacks (Boal 1972; Doherty and Poole 1997). This intuition was later tested in a systematic and quantitative manner by Cunningham and Gregory (2014), who found that it was indeed in homogeneous sanctuary spaces that the conflict became most deadly. Mueller et al. (2019) confirm that violence occurred both in the homogeneous sanctuaries and in the interfaces where the two groups met.

This duality encapsulates the debate that animates empirical studies of conflict intensity. Some studies find that diversity (defined in this particular case as the collocation of two ethnic groups with roughly equal population shares) predicts greater violence (Balcells, Daniels, and Escribà-Folch 2016; Costalli and Moro 2012; Posen 1993; Toft 2003; Weidmann 2011). ${ }^{1}$

\footnotetext{
${ }^{1}$ Our study focuses on a simple case with two ethnic groups. We discuss extensions to cases with
} 
Other studies find the exact opposite, that diverse areas are less violent (Fjelde and Hultman 2014; Hägerdal 2019; Kasara 2016; Mesev, Shirlow, and Downs 2009; Mueller, Rohner, and Schönholzer 2019).

It is noteworthy that the disaggregated subnational studies associating ethnic diversity with less violence, specifically in civil war, share a common problem: they rely on demographic measures collected after conflict onset (Hägerdal 2019; Mesev, Shirlow, and Downs 2009; Mueller, Rohner, and Schönholzer 2019). These measures are confounded by large population movements that occurred in the conflict's early days, limiting our ability to draw inferences about the role that demographic patterns played during the conflict. This is particularly true in the context of the Troubles, which broke out in 1969 with "one of the largest movements of civilian populations in postwar Europe" (Feldman 1991). These problems are compounded by other difficulties that lead to the systematic undercounting of minority groups in ethnic conflict settings (Kopstein and Wittenberg 2011). Persecuted ethnic groups fearful for their safety may resist the census and violent actors may target censusrelated infrastructure. Both phenomena occurred in our study area of Belfast (O'Connor 1971; Gallagher 1971; Fermanagh Herald 1971; Sunday Independent 1971). It is likely that existing census-based studies underestimate both the presence of Catholics and the association between diversity and conflict intensity, biasing the estimated relationship between the two variables toward zero. Even studies using preconflict data risk undercounting minority groups who are reluctant to reveal their ethnicity to census researchers. Studies arguing that diversity intensifies conflict may be understating the strength of their own results (Costalli and Moro 2012).

We propose a solution to this problem with a novel measure of demographic patterns that is not confounded by violence, census resistance, or population movements in the early days of the conflict: the geographic location of churches. We present an original dataset of 264 Churches - 225 Protestant Churches and 39 Catholic Churches - in the city of Belfast when more numerous ethnic groups in the concluding section. 
the conflict broke out in 1969. The churches in our dataset were constructed in the 17th20th centuries, and we excluded any church built after 1969. (No churches were destroyed by the violence.) The Industrial Revolution, particularly the growth of Belfast's linen and shipbuilding industries, initiated a massive expansion of Belfast's urban population, from 53,000 in 1831 to over 400,000 a century later (Northern Ireland Statistics and Research Agency 2005). This population growth triggered a construction boom in residential housing and religious facilities, as employers commissioned affordable housing near their mills and religious orders sought to provide sufficient pews within easy walking distance of Belfasters' homes (Bardon 1982; Irvine 1991; McGee 2013). Thus, the locations of the churches in our dataset provide a snapshot of Protestant and Catholic settlement patterns, which long preceded the Troubles.

Unlike the 1971 census data used in other studies, our measure of Protestant and Catholic settlement is not confounded by census resistance or the population dislocations that occurred in 1969 and 1970 as the conflict flared up. We join our new measure of churches with existing data on conflict deaths (CAIN 2014) during the Troubles. These data allow us to identify empirical patterns that do not suffer from measurement bias caused by conflict-driven changes in population. ${ }^{2}$

Our findings are twofold. First, we show that church diversity and conflict deaths have a curvilinear relationship, with the steepest positive slope in the bottom third of church diversity. In other words, the enclaves were not especially violent, in and of themselves; rather, a marginal increase in diversity near the most homogeneous areas had the strongest effect on violence. Second, our data reveal that the main driver of this pattern is the incremental increase in the Catholic proportion of church density, particularly at low levels. The greatest marginal increase in violence occurs as the Catholic proportion of church density increases from zero toward twenty percent. There is no similar effect when increasing the

\footnotetext{
${ }^{2}$ Following Hancock 1998, we treat Catholic and Protestant groups in Northern Ireland as ethnic identities: "The Northern Ireland Troubles fit the definition of an ethnic conflict between Catholic nationalists and Protestant unionists, each side with its own distinct ancestry, cultural traditions, and sense of identity."
} 
Protestant share of church density from very low levels.

Together, we argue, these empirical patterns are consistent with a story of violence motivated by the threat of outgroup exposure. A rich literature in the social sciences demonstrates that mere exposure to an outgroup, whether it be an ethnic-other (Adida, Laitin, and Valfort 2015; Enos 2014), a refugee (Dinas et al. 2019), or an immigrant (Newman, Hartman, and Taber 2012), increases exclusionary attitudes and behaviors toward that outgroup. This is precisely what happened in the lead-up to The Troubles. When Catholics comprised only a small minority of Belfast's population, interethnic violence was rare - in fact, Protestants contributed much of the funding to build Belfast's first and second Catholic churches, in 1784 and 1815 (Irvine 1991). Interethnic relations soured only as the Catholic population grew from this small, pre-industrial baseline. As Belfast industrialized and poor Catholics moved to the city for work, the increase in the Catholic population and the perceived presence of a "reservoir" of additional rural Catholics, ready to "invade" Protestants' neighborhoods and take their jobs, created an environment of perceived scarcity and competition (Boal 1982; O'Hearn 1983). The threat to Protestant hegemony was particularly acute in diversifying areas, and this dynamic is reflected in our Troubles-era data: violence is relatively low when all the nearby churches are Protestant, but even a slight increase in the density of Catholic churches produces dramatic increases in the number of conflict deaths.

Our paper makes three distinct contributions. First, it builds on the rich literature on the empirical study of conflict intensity (Balcells 2010; Kalyvas 2006). Our curvilinear result reconciles claims that ethnic diversity exacerbates violence (Costalli and Moro 2012; Balcells, Daniels, and Escribà-Folch 2016; Posen 1993; Schutte 2017) and claims that diversity attenuates violence (Hägerdal 2019; Kasara 2016; Mesev, Shirlow, and Downs 2009; Mueller, Rohner, and Schönholzer 2019). Second, our paper contributes to the nuanced discussion of the deleterious effects of outgroup exposure in contrast to the potentially prejudice-reducing effects of outgroup contact. Because Belfast's ethnic populations tend to self-segregate socially (), violence-reducing social contact and social capital mechanisms do not operate 
effectively (Allport 1954; Glaeser 2005; Jha 2013; Putnam 1994; Varshney 2001). In diverse but socially segregated neighborhoods, exposure to the ethnic other intensifies fears, hatreds, and the resulting conflict violence. Third, our paper proposes a new method of measuring population patterns before conflict and the potentially confounding migration that results. Identifying unbiased data is particularly challenging in ethnic civil war contexts because atrisk minorities may be under-counted (Kopstein and Wittenberg 2011) and violence tends to upset settlement patterns, triggering migration away from diverse areas (Boal 1982; Irvine 1991). Both of these problems bias measures of diversity toward zero. Our method allows researchers to recover the underlying population patterns as they existed prior to conflict, enabling unbiased estimates of diversity and its effects on conflict dynamics.

\section{Do diverse neighborhoods exacerbate or alleviate con- flict intensity?}

Ethnic settlement patterns, such as the diversity or homogeneity of a given area, can influence the intensity of violence once civil war breaks out (Hägerdal 2019; Klašnja and Novta 2014; Weidmann 2011). ${ }^{3}$ Diversity's influence may operate through a number of different mechanisms. The historic experience of collocation with an equally large ethnic group generates competitive dynamics and "homelands" that may overlap on a given tract (Toft 2003; Weidmann 2011). Population parity gives both ethnic groups an expectation that fighting could bring victory and control of the land (Costalli and Moro 2012; Tilly 1978). Diversity may also generate security dilemma dynamics between the collocated ethnic groups; mutual vulnerability and suspicion increase the incentive to strike first and continue fighting until the other group is killed or expelled (Posen 1993). A separate body of civil war literature explains violence patterns based on informational factors within the conflict. In areas of

\footnotetext{
${ }^{3}$ Our analysis pertains to ethnic civil war intensity, specifically whether ethnically diverse areas experience more deaths. It also deals with "irregular" or "guerrilla" civil wars, as opposed to "conventional" civil wars with distinct front lines (Balcells and Kalyvas 2014).
} 
contested control, it is difficult for conflict actors to distinguish combatants from civilians. These contested areas experience the most indiscriminate violence against civilians, but areas of partial control, where a marginally dominant group can identify and "cleanse" the other side's agents, see the most combatant fatalities (Kalyvas 2006). Extending this logic to ethnic civil war, diverse neighborhoods represent zones of contested control and we should expect more indiscriminate violence against civilians there.

Other studies argue that diversity decreases conflict intensity via several distinct mechanisms. First, ethnic concentration, as one finds in segregated stronghold areas, facilitates violent collective action (Weidmann, Rød, and Cederman 2010). The capacity for violence dissipates as one moves away from stronghold areas, so diverse zones should see less violence. Two previous studies find support for this argument in our research area of Belfast (Mesev, Shirlow, and Downs 2009; Mueller, Rohner, and Schönholzer 2019). Second, ethnic groups may prefer to spend their resources targeting one another's strongholds in symbolic tit-for-tat killings (Fjelde and Hultman 2014). Third, diversity may enable better information gathering and more discriminate violence, because coethnics are available to serve as informants among the ethnic outgroup (Hägerdal 2019). (This argument contradicts informational theories that predict greater indiscriminate violence in contested areas.)

An entirely different literature rooted in social psychology offers equally ambiguous predictions. On one hand, social contact and social capital theories give us reason to expect less violence in diversely settled areas. A history of interaction may promote intergroup trust and understanding rather than enmity (Allport 1954). Such intergroup contact can reduce prejudice, decreasing individual incentives for violence (Hewstone and Swart 2011; Lowe Forthcoming; Lemmer and Wagner 2015; Mousa 2020; Pettigrew and Tropp 2008). When ethnic groups interact in shared social organizations and economic activities cutting across ethnic lines, "bridging social capital" enables elites to manage tensions and resolve disputes (Glaeser 2005; Jha 2013; Putnam 2000; Varshney 2001). In Kenya, for example, ethnically diverse areas experienced less violence in the country's 2008/9 post-election crisis (Kasara 
2016).

At the same time, exposure to outgroups can increase prejudice and exclusion (Rae, Newheiser, and Olson 2015), particularly among individuals with pre-existing biases (Schieferdecker and Wessler 2017). This negative effect of exposure manifests behaviorally as well. In a lab-in-the-field experiment examining the integration experience of Muslim immigrants in France, Adida et al. (2015) find that French participants gave less money to Muslim immigrant game partners (relative to Christian immigrant game partners) when they were exogenously placed in a room with more Muslim immigrants around them. And in the real world, in the aftermath of the 2015 Syrian refugee crises, Dinas et al. (2019) show that Aegean islands that randomly received more Syrian refugees saw greater increases in vote shares for the far-right party than did Aegean islands with fewer Syrian refugees. An implication of this literature is that ethnically diverse areas should see more violence because of this group-threat via exposure effect.

\section{A new measure}

The disagreement over diversity's relationship with violence is exacerbated by a fundamental measurement error. Conflict displaces people, making it difficult to capture an accurate snapshot of demographic settlement patterns that have not already been shaped by violence.

Seeking safety in numbers, residents flee contested areas and relocate to areas controlled by their ethnic group. In Belfast, the August 1969 onset of violence was responsible for at least eight deaths, the destruction of 150 Catholic homes, and the dislocation of 2,069 families, mostly from diverse areas (CAIN 2014; Coogan 1993; Griffiths 1971). Within weeks, 75\% of Belfast residents retrenched to areas that were $90 \%$ Protestant or $90 \%$ Catholic (Boal 1982; Irvine 1991). Census data collected after conflict onset understate the degree and spatial extent of pre-conflict diversity, biasing the estimated relationship between diversity and violence toward zero. 
A related problem involves measurement error in data collected during a conflict - or even prior to it. Many Belfast residents feared that their 1971 census answers would be shared with police. The fear was disproportionately high among Catholics, as priests and Catholic school teachers encouraged their coethnics not to fill out the forms (O'Connor 1971). Compounding matters, Irish Republican militants encouraged Catholic census resistance and set fire to the Ministry of Finance where completed forms were kept (Gallagher 1971; Fermanagh Herald 1971; Sunday Independent 1971) The resulting measurement error - undercounting of Catholics, particularly in paramilitary-dominated neighborhoods and mixed areas where anonymity might be necessary for self-preservation - is likely to understate the amount of diversity in the most violent zones, biasing the estimated relationship between the two variables toward zero.

We propose a new measure of ethnic neighborhood composition that eschews these challenges by relying on the spatial distribution of Catholic and Protestant churches built before 1969. We rely on multiple sources to find the locations of these churches. We first compiled a list of churches that currently hold religious services from the websites of Ireland's five main Christian denominations: Catholics (39 churches within three kilometers of Belfast), Baptists (25), Presbyterians (83), Methodists (42), and the Church of Ireland (75). ${ }^{4}$ We then consulted historical sources and emailed the parish offices of all denominations to identify derelict or demolished churches that were open before the onset of the Troubles. We confirmed, using parish histories and other secondary sources, that all the churches in our database predate August 1969. We geolocated each church using street addresses from church websites and historic street directories. Using Google Maps' satellite imagery and public API, we confirmed each structure's latitude and longitude. ${ }^{5}$ Figure 1 shows the locations of these churches.

Our data on the location of violent deaths come from the Conflict Archive on the Internet

\footnotetext{
${ }^{4}$ These denominations represent $95 \%$ of churchgoers in Northern Ireland, according to the 2011 census.

${ }^{5}$ Our replication data notes list the sources consulted.
} 

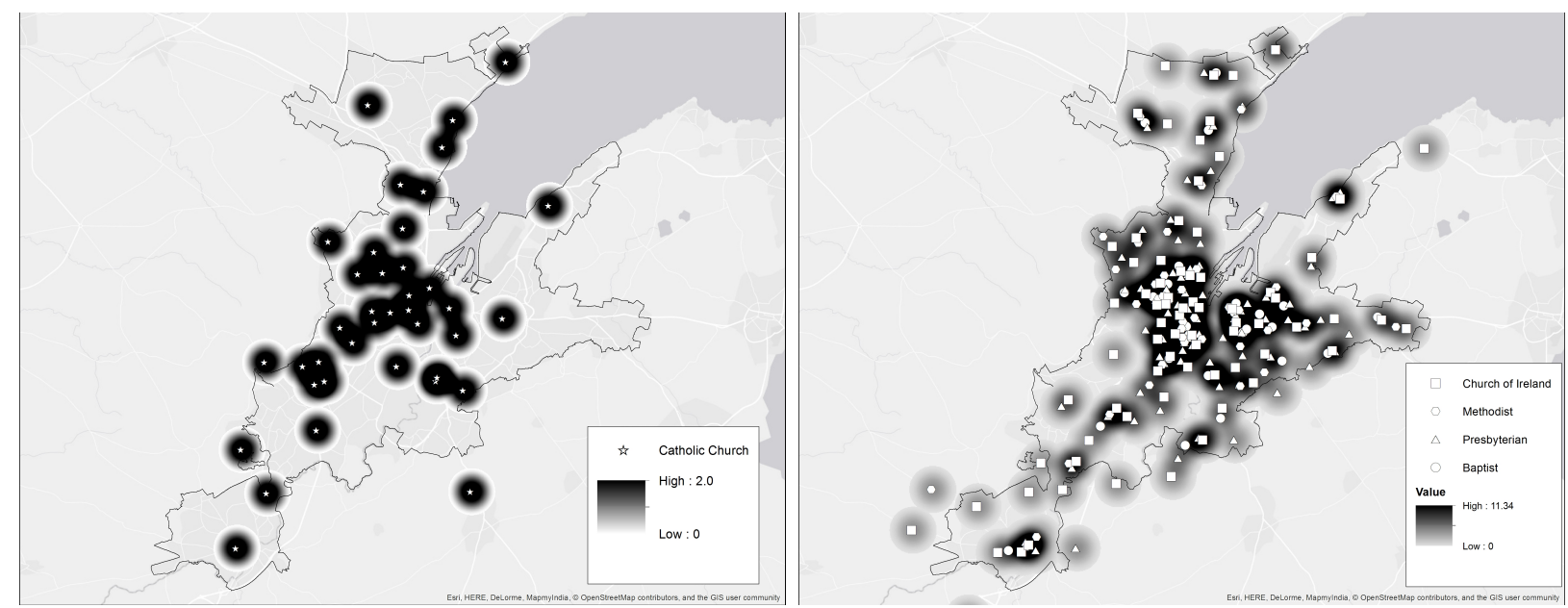

Figure 1: Left: Catholic churches, location and kernel density with 1 kilometer bandwidth. Right: Protestant churches, location and kernel density with 1 kilometer bandwidth.

(CAIN) project at the University of Ulster CAIN. Researchers geolocated the 3,379 civilian and combatant deaths during the Troubles to the exact street address, making the data available as a Google Maps layer, which we scraped from the public XML file. ${ }^{6}$ Figure 2 plots these conflict-related deaths, surrounded by 500 meter bandwidth kernels. It shows that the density of deaths is particularly high in West Belfast, a thickly-settled area where working class Protestants and Catholics lived in close proximity (Boal 1969). The density of deaths is also high in Belfast's commercial center, frequented by Protestants and Catholics alike.

We use the location of churches predating the 1969 onset of the Troubles to construct a pre-conflict measure of ethnic diversity. We estimate kernel densities stretching out from each church, generating 25-meter grids of each denomination's church density per square kilometer in Belfast. For robustness, we construct kernels stretching 1 kilometer, 1.5 kilometers, 2 kilometers, and 3 kilometers from the church and we report results at varying kernel

\footnotetext{
${ }^{6}$ Original data available at http://cain.ulst.ac.uk/victims/gis/googlemaps/victims . html. CAIN is not the only source of geospatial data from the Troubles. The Northern Ireland Research Initiative (NIRI) estimates the locations of violent events using machine learning (Loyle, Sullivan, and Davenport 2014). However, the NIRI dataset contains significant errors - for instance, assigning over 80 deaths to one point in central Belfast and over 30 to a field west of Belfast. These locations are unsupported by qualitative accounts of the conflict (McKittrick et al. 2001).
} 


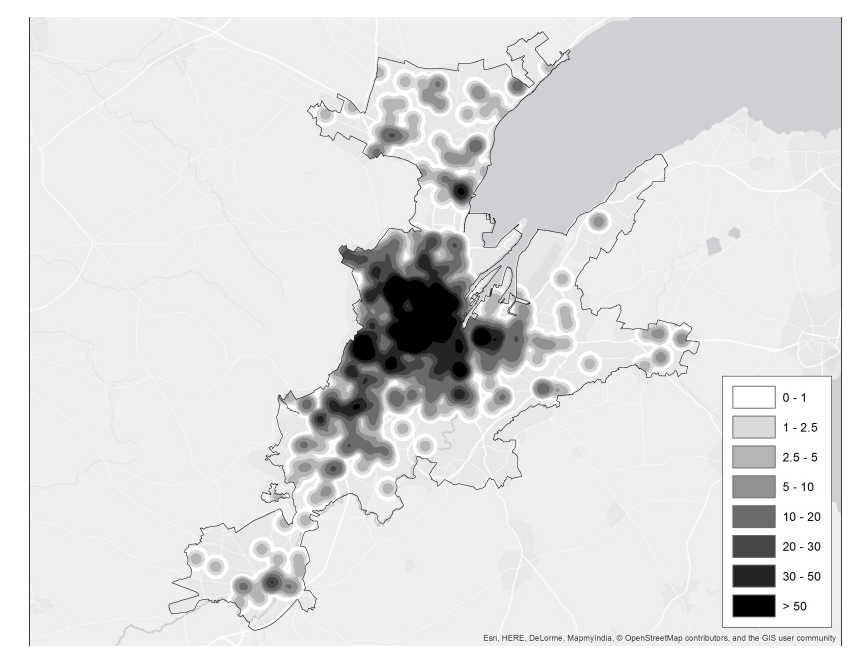

Figure 2: Plot of 500 meter bandwidth kernel density of deaths. Darker shades represent more violent areas.

bandwidths. We construct the measure for the ethnic diversity of the population by creating a variable for "church diversity" in each grid cell. Our measure follows the form of Montalvo and Reynal-Querol (2010)'s $R Q$ :

$$
\text { ChurchDiversity }=1-\left[\left(\frac{0.5-\pi_{\text {Cath }}}{0.5}\right)^{2} \pi_{\text {Cath }}+\left(\frac{0.5-\pi_{\text {Prot }}}{0.5}\right)^{2} \pi_{\text {Prot }}\right]_{i}
$$

where $\pi_{\text {Cath }}$ denotes the Catholic church density in that location divided by the sum of Catholic and Protestant church densities, while $\pi_{\text {Prot }}$ has an analogous definition for Protestant church density. This church diversity measure is closely related to the Herfindahl index, which takes the form $1-\frac{R Q}{2}$ for a two-group setting. ${ }^{7}$ Crucially, our measure represents church diversity, rather than church density. This is important because a church diversity measurement is not confounded by population density.

Based on our new measure, cells with a value close to 1 have a similar density of Protestant and Catholic churches, indicating a highly diverse community. Cells with a value near zero have significantly more Catholic or more Protestant churches, indicating low diversity.

\footnotetext{
${ }^{7}$ Our findings are robust to using Ethnolinguistic Fractionalization instead - see Appendix Table A1 and Figure A2. In the conclusion, we discuss potential extensions for more than two groups.
} 
Cells with neither Catholic nor Protestant churches within a given kernel bandwidth have no value for the measure and are not included in regressions at that kernel bandwidth. Figure 3 maps the church diversity measure for the 1 kilometer bandwidth. Allowing for the potential confounding effect of population density, we note a visual correspondence between the presence of darker, more diverse zones and the violent dark spots shown in Figure 2. The many overlapping Catholic and Protestant church kernels of West Belfast, in particular, correspond to a high density of deaths in an area that was both thickly and diversely settled - and exceedingly violent. However, it is also important to note that an area such as West Belfast may contain a complex patchwork of mixed Protestant/Catholic blocks, segregated blocks, and contested streets where majority Catholic and majority Protestant blocks abut (Boal 1969). Our ability to measure diversity at a highly disaggregated level allows us to determine which settlement patterns predict more violence: segregated enclaves, fully mixed neighborhoods, or neighborhoods where one ethnic group dominates but its hegemony is threatened by the presence of a minority of households from the other ethnic group.

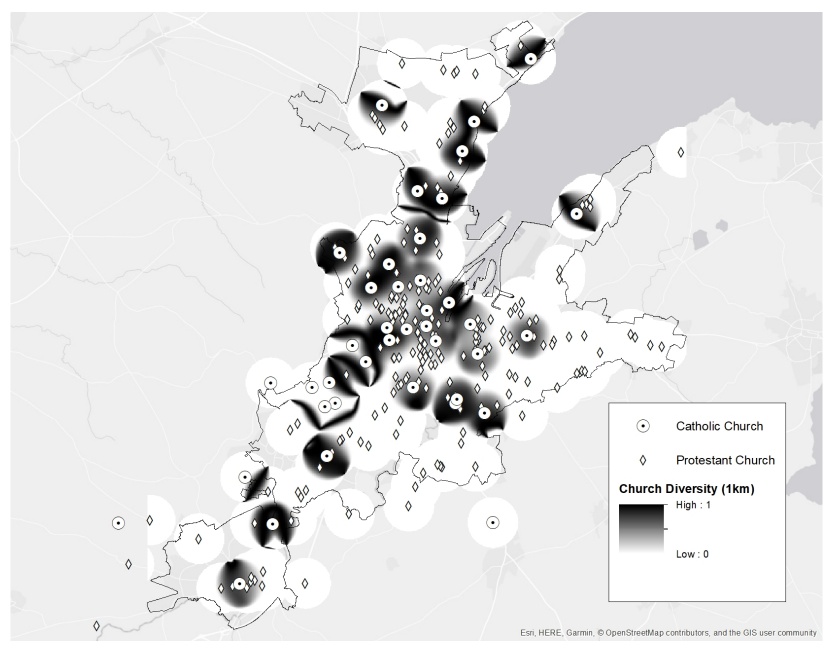

Figure 3: Diversity of churches constructed from Catholic and Protestant kernel densities in Belfast. Darker areas are more mixed in church density. 


\section{Estimation and Results}

\subsection{Summary Statistics}

Table 1: Summary Statistics

\begin{tabular}{lccccc}
\hline & $(1)$ & $(2)$ & $(3)$ & $(4)$ & $(5)$ \\
VARIABLES & N & mean & sd & min & $\max$ \\
\hline & & & & & \\
Victims in Grid Cell & 8,258 & 0.196 & 0.904 & 0 & 23 \\
Church Diversity (1 km bw) & 7,931 & 0.287 & 0.343 & 0 & 1 \\
Church Diversity (1.5 km bw) & 8,196 & 0.391 & 0.320 & 0 & 1 \\
Church Diversity (2 km bw) & 8,255 & 0.392 & 0.299 & 0 & 1 \\
Church Diversity (3 km bw) & 8,258 & 0.472 & 0.228 & 0 & 1 \\
Distance (m) to nearest Protestant church & 8,258 & 463.0 & 325.5 & 10 & 2,075 \\
Distance (m) to nearest Catholic church & 8,258 & 1,111 & 877.2 & 11 & 5,846 \\
Population & 8,258 & 71.19 & 76.66 & 1 & 1,438 \\
Population without Hot Water & 5,451 & 0.0851 & 0.192 & 0 & 0.98 \\
Population without Bath or Shower in Home & 5,451 & 0.137 & 0.288 & 0 & 1 \\
Population without Inside Toilet & 5,451 & 0.142 & 0.287 & 0 & 1 \\
& & & & & \\
\hline
\end{tabular}

Table 1 presents summary statistics on the variables used in the analysis. There are 8,258 locations within Belfast included in the 1971 census, from which we source the household asset variables. ${ }^{8}$ The data on victims have been mapped to those locations. Only 5,451 locations have data on assets. Distance to nearest church is calculated with GIS, and together with the church diversity variable are aggregated to 100-meter grids that match the 1971 census grids. These 100-meter grids are our unit of observation.

\subsection{Church Diversity and Violence}

We begin by exploring the association between church diversity and the location of conflict deaths. Figure 4 shows the association in the raw data, at various bandwidths for the

\footnotetext{
${ }^{8}$ Because they are drawn from the 1971 Census, these control variables are prone to the same measurement bias we describe in this paper. As a result: (a) we run all our regressions with and without these variables: our results without these controls, which are unchanged, are presented in Table A2 and Figure A3 in the Appendix; (b) we acknowledge here that we are introducing possible endogeneity on the right-hand side, which would bias our estimates toward zero and thus make it more difficult to uncover a relationship that exists; and (c) we note that conflict migration and intimidation should not have an effect on the description of household assets the way it may affect respondent identification.
} 


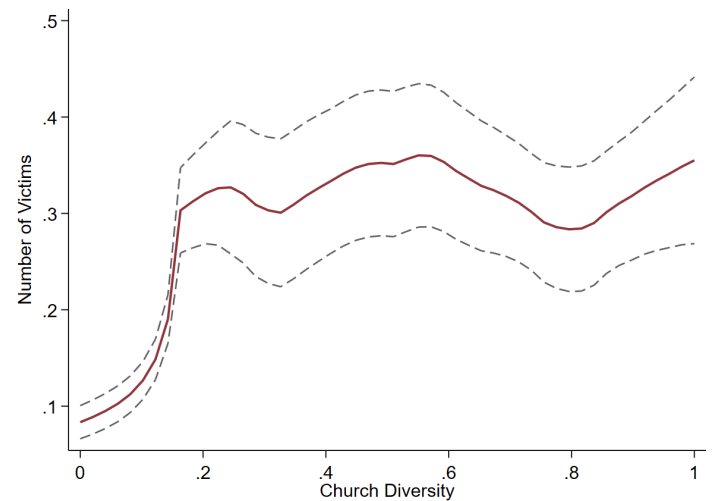

(a) $1 \mathrm{~km}$

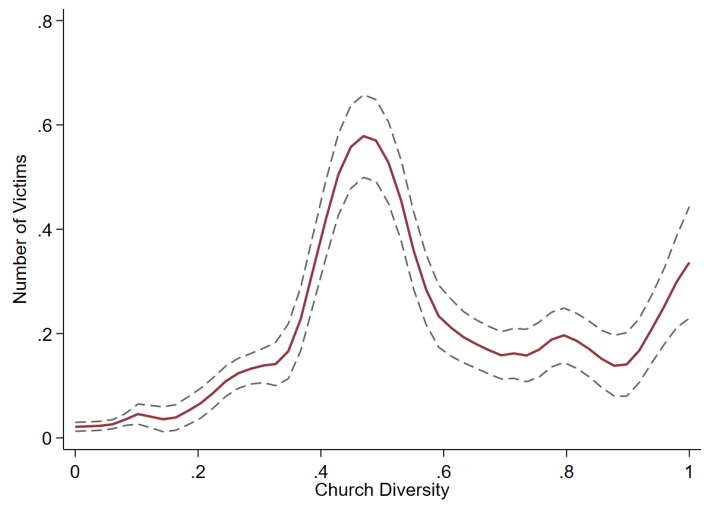

(c) $2 \mathrm{~km}$

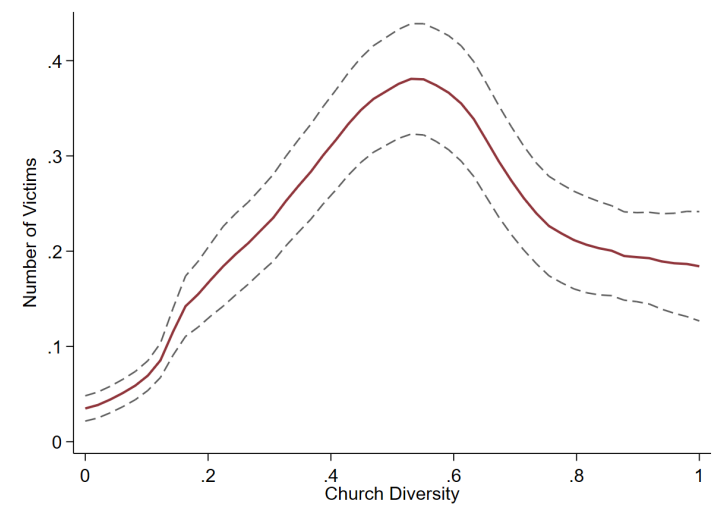

(b) $1.5 \mathrm{~km}$

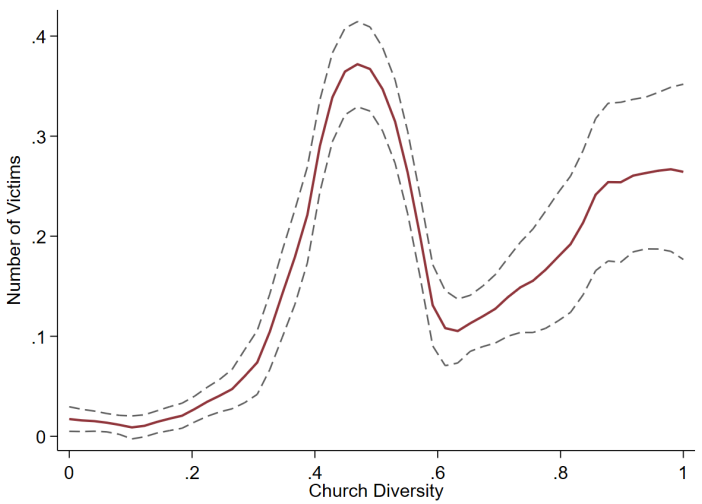

(d) $3 \mathrm{~km}$

Figure 4: Local polynomial fit of number of victims in grid cell on church diversity measure. Dotted lines indicate 95\% confidence intervals.

construction of the church diversity measure. For all four bandwidths, the number of deaths per grid cell is lowest in locations where church diversity is near zero (complete homogeneity), and rises to significantly higher levels of deaths starting at a church diversity of 0.2 . At the smaller bandwidth of $1 \mathrm{~km}$, there is a rapid increase of violence up to a church diversity value of 0.2 , which flattens thereafter. At larger church diversity bandwidths, violence increases beginning at 0.2 and peaks between 0.4-0.6. At levels of church diversity above 0.6 , violence decreases as church diversity approaches 1, though violence levels always remain above those at zero church diversity (homogeneous neighborhoods).

Since the relationship between church diversity and violence might be confounded by other variables, given the role that socioeconomic class has played in the conflict (Feldman 
1991), we control for population density and socioeconomic characteristics of households. Given that our dependent variable is a death count, we employ a Poisson specification. We note here that our results hold using a negative binomial specification instead (see Appendix Table A3 and Figure A4). We specify a quadratic of the church diversity variable and control for the $\log$ of distance to the nearest Catholic church and Protestant church to measure separately the association of deaths to church diversity and church proximity. We control for the log of population density and three socioeconomic variables available in the census: the proportion of households in the grid cell without hot water, the proportion without bath or shower in the home, and the proportion without an inside toilet. To adjust inference for spatial autocorrelation, we cluster standard errors using 1993 electoral ward boundaries (the earliest available as a shapefile ${ }^{9}$ ). This clustering has no effect on our coefficients, but it offers a more conservative assessment of the statistical significance of our results.

Table 2 shows the results of these Poisson estimations. Column (1) estimates the association between victims and a linear term in church diversity, calculated at a $1 \mathrm{~km}$ bandwidth. The coefficient of 0.64 , significant at pi0.1, suggests that cells with a church diversity of 1 have around $90 \%^{10}$ more deaths than those with a church diversity of zero (the mean number of victims per grid cell in the estimation sample is 0.23$)$. This association between violence and church diversity is independent of proximity to the nearest Catholic or Protestant church. Column (2) shows the same church diversity variable with a $1 \mathrm{~km}$ bandwidth in a quadratic specification, which is not significant likely due to insufficient variation in the church diversity variable at this smallest bandwidth (histograms for all bandwidths are shown in Appendix Figure A1).

Column (3) constructs the church diversity variable at a larger bandwidth of $1.5 \mathrm{~km}$. Both the linear and the quadratic terms are strongly significant $(\mathrm{p}<0.01$ and $\mathrm{p}<0.05)$, and suggest that violence is highest when diversity equals 0.73 . This estimate for the level

\footnotetext{
${ }^{9}$ Ward boundaries downloaded from Open Data NI, https://www.opendatani.gov.uk/ dataset?q=boundary

${ }^{10} \mathrm{We}$ calculate the increase in deaths by taking the exponent of the regression coefficient: $e^{.64}$
} 
Table 2: Victims and Church Diversity

\begin{tabular}{|c|c|c|c|c|c|}
\hline Church diversity kernel bandwidth: & $\begin{array}{c}(1) \\
1 \mathrm{~km} \\
\end{array}$ & $\begin{array}{c}(2) \\
1 \mathrm{~km} \\
\end{array}$ & $\begin{array}{c}(3) \\
1.5 \mathrm{~km} \\
\end{array}$ & $\begin{array}{c}(4) \\
2 \mathrm{~km} \\
\end{array}$ & $\begin{array}{c}(5) \\
3 \mathrm{~km} \\
\end{array}$ \\
\hline Church Diversity & $\begin{array}{l}0.640^{*} \\
(0.373)\end{array}$ & $\begin{array}{l}0.0137 \\
(0.972)\end{array}$ & $\begin{array}{c}3.848^{* * *} \\
(1.358)\end{array}$ & $\begin{array}{c}5.194^{* * *} \\
(1.627)\end{array}$ & $\begin{array}{c}6.717^{* * *} \\
(1.852)\end{array}$ \\
\hline Church Diversity Squared & & $\begin{array}{c}0.634 \\
(1.035)\end{array}$ & $\begin{array}{c}-2.645^{* *} \\
(1.153)\end{array}$ & $\begin{array}{c}-3.363^{* *} \\
(1.616)\end{array}$ & $\begin{array}{c}-4.164^{* * *} \\
(1.557)\end{array}$ \\
\hline Observations & 5,386 & 5,386 & 5,451 & 5,451 & 5,451 \\
\hline \multicolumn{6}{|c|}{$\begin{array}{l}\text { Notes: Results from Poisson estimations, with number of victims as the dependent variable, } \\
\text { church diversity constructed at } 1 \mathrm{~km} \text { (column } 1 \text { as a linear term, column } 2 \text { quadratic), } 1.5 \mathrm{~km} \\
\text { (column } 3), 2 \mathrm{~km}(4) \text { or } 3 \mathrm{~km}(5) \text { bandwidths. Regressions control for log distance to nearest } \\
\text { Catholic church, log distance to nearest Protestant church, log population as well as three } \\
\text { ariables for proportion of households without hot water, without a bath or shower, and without } \\
\text { an inside toilet. Coefficients for these distance, population and SES controls, as well as for the } \\
\text { onstant term, are not shown. Standard errors are clustered by } 116 \text { wards using } 1993 \text { boundaries } \\
\text { and significance levels are denoted at conventional levels }{ }^{* * *} \mathrm{p}<0.01,{ }^{* *} \mathrm{p}<0.05,{ }^{*} \mathrm{p}<0.1 \text {. }\end{array}$} \\
\hline
\end{tabular}

of diversity associated with the highest level of violence increases slightly to 0.77 when the church diversity bandwidth is $2 \mathrm{~km}$ (column 4) and to 0.81 at the largest bandwidth of $3 \mathrm{~km}$ (column 5). Figure 5 plots marginal effects of church diversity on violence for each bandwidth. With the exception of the smallest bandwidth - where there is much less variation - the greatest effect on violence of a marginal increase in church diversity occurs when church diversity is in the 0.3-0.5 range. 


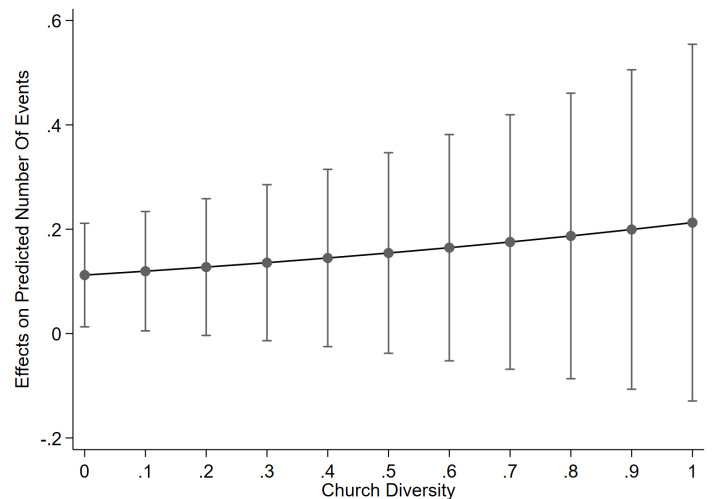

(a) $1 \mathrm{~km}$

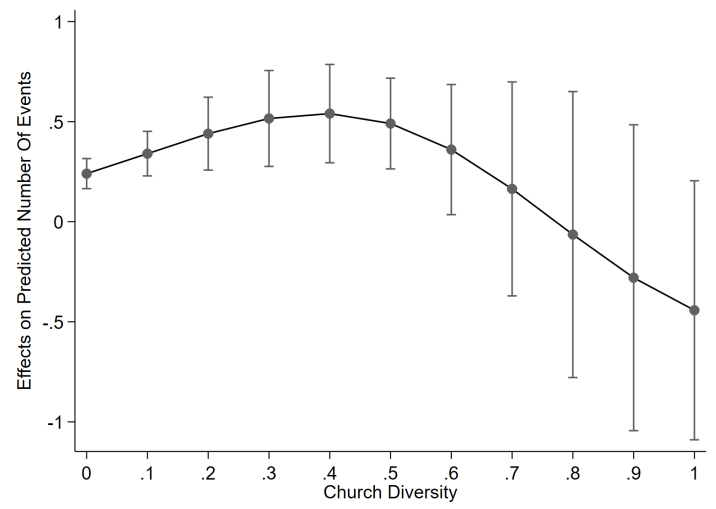

(c) $2 \mathrm{~km}$

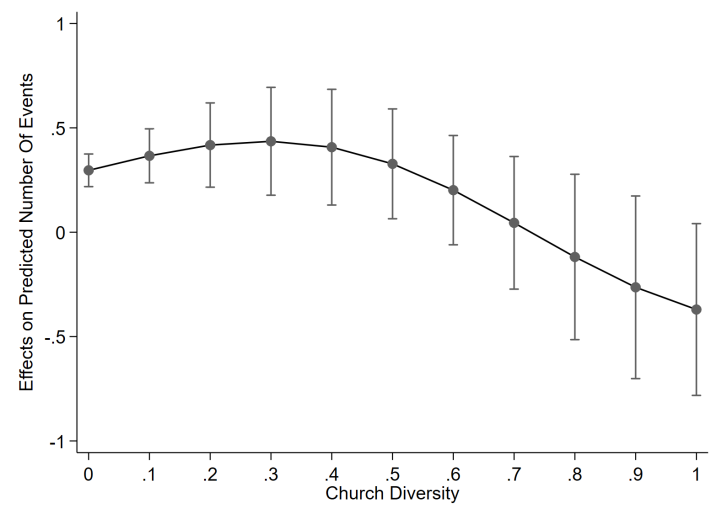

(b) $1.5 \mathrm{~km}$

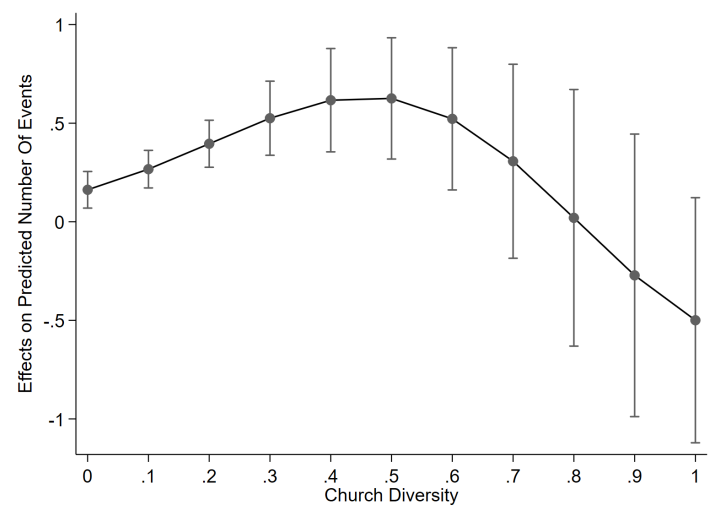

(d) $3 \mathrm{~km}$

Figure 5: Marginal Effects of Church Diversity on Violence

In Figure 6, we further investigate what drives this curvilinear pattern by separating out the effect of Catholic vs. Protestant diversification. In other words, we distinguish between geographical units where Catholics are the minority and those where Protestants are the minority. A theory of group threat leads us to expect that violence should increase as the stigmatized minority ethnic group (in this case Catholics) begins to increase its population share. The same logic does not hold for the more privileged group, in this case Protestants. Figure 6 investigates these possibilities, showing the predicted level of violence for each $10 \%$ bin of the Catholic (top three figures) or Protestant (bottom three figures) proportion of church diversity. (The subfigures representing the Catholic proportion are mirror images of the corresponding Protestant subfigures.) Note that the greatest marginal increase in predicted deaths occurs as Catholic church density (and by implication, Catholic citizens) 

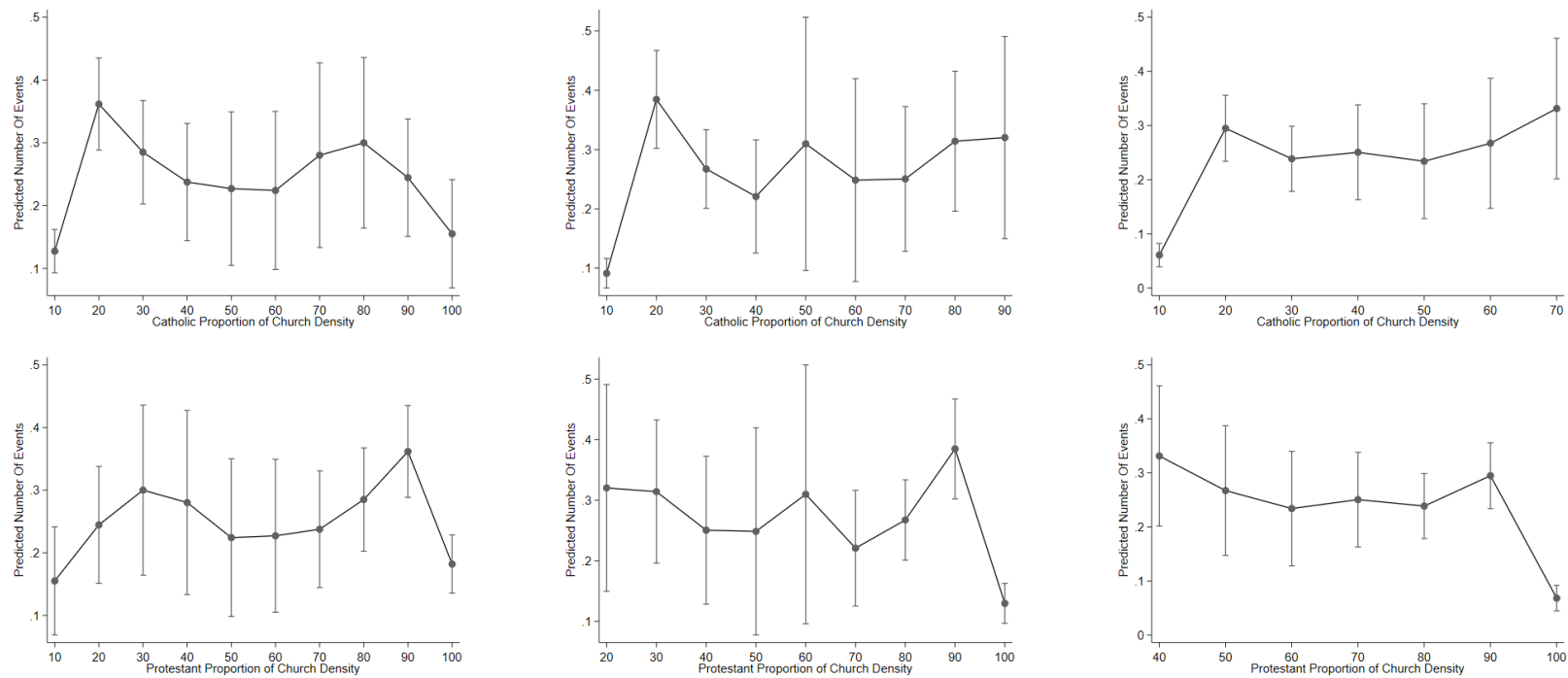

(a) $1.5 \mathrm{~km}$

(b) $2 \mathrm{~km}$

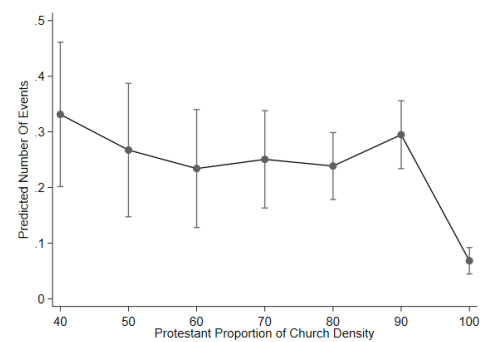

(c) $3 \mathrm{~km}$

Figure 6: Predicted Violence, by 10\% bins of Catholic or Protestant proportion of Church Diversity, by church density bandwidth

increase from a negligible $0-10 \%$ share to a slightly greater $10-20 \%$ share density. The same trend is not observed when Protestants' share of church diversity increases from negligible levels. This suggests that incremental increases in the stigmatized minority Catholic population are the greatest driver of Belfast's interethnic violence. This finding is consistent with a theory of group threat via exposure. It is further corroborated by qualitative accounts tracing Belfast's earliest reported ethnic tensions to the industrial migration of rural Catholics to working class neighborhoods that were almost completely Protestant before (O'Hearn 1983).

Given that the variance of the dependent variable is larger than its mean (Table 1), we guard against erroneous results from overdispersion by repeating the analysis using a negative binomial model. Results are qualitatively unchanged, with the greatest marginal effect of diversity still occurring at a church diversity of around 0.5 (see Appendix Table A3 and Figure A4). We also test whether results might be driven by deaths in the 1980s or 1990s, which would be problematic if the pre-1969 church distribution measure no longer reflects the ethnic distribution decades later. Table A4 shows that the association between church diversity and violence is unchanged if deaths after 1980 or deaths after 1990 are not 
included in the analysis. Church diversity associated with highest levels of violence remains very consistent, regardless of how many later deaths are excluded, at 0.70-0.73 for the 1.5 $\mathrm{km}$ bandwidth, 0.75-0.79 for the 2km bandwidth, and 0.73-0.81 for the $3 \mathrm{~km}$ bandwidth.

\section{Conclusion}

The effect of diversity on conflict is difficult to characterize. Results from rich literatures on conflict and on intergroup prejudice provide arguments for either a positive or a negative relationship. As a result, the verdict remains a largely empirical endeavor. Yet empirical analyses face their own set of challenges. In this paper, we highlight one impediment to identifying an unbiased estimate of the effect of ethnic diversity on conflict intensity: the fact that conflict generates migration and measurement error. Any research design that does not account for conflict-induced migration and measurement error leads to biased estimates, limiting our ability to draw valid inferences about the relationship between diversity and violence.

In the face of these challenges, the case of the Troubles in Northern Ireland offers a unique opportunity: a data-rich context where physical structures reflect underlying demographic patterns. In this paper, we introduce this new dataset and offer an analysis that is not mired by the measurement bias that conflict and conflict-migration create. This analysis uncovers two key empirical results: the relationship between diversity and violence is curvilinear, with the strongest effects occurring at low-to-mid levels of diversity; and incremental increases in the Catholic proportion of church density are most associated with increased violence. Together, these results are consistent with a story of violence through group-threat exposurea narrative further corroborated by qualitative accounts of the historical relationship between Catholics and Protestants in Northern Ireland. Indeed, as others have noted, Protestants

were quite accommodating of Catholics when they represented only a small proportion of Belfast's population; they grew increasingly suspicious and hostile as more Catholics moved 
into the city, threatening the Protestants' dominant demographic and social position (Boal 1982; O’Hearn 1983).

Our method opens opportunities for future research. First, using physical structures as unbiased measures can alleviate data limitations in the analysis of other ethnic conflicts. Two thirds of countries record no ethnicity data in censuses (Aktürk 2012). Physical structures could proxy for ethnic settlement patterns in these countries (e.g. Turkey, France) and in countries where censuses undercount particular groups (Kopstein and Wittenberg 2011). Second, our empirical approach might be extended to qualitatively different contexts, such as ideological wars or ethnic civil wars with conventional front lines. In conventional civil wars, belligerents strategically eliminate the opposing side's civilian supporters from territory they conquer (Balcells 2011). Using physical structures to measure prewar settlement patterns would enable research on behind-the-lines civilian victimization in conventional ethnic civil wars. It could also enable research on irregular ideological civil wars, if appropriate physical instruments exist for the ideological composition of a given area.

Substantively, our research aligns with recent work showing that changes in diversity, rather than absolute levels of diversity, are most threatening (Cikara, Fouka, and Tabellini 2020; Hopkins 2010; Newman and Velez 2014). Catholic migration to Belfast did not become contentious until the Catholic population share grew beyond its negligible pre-industrial levels. But even as our research affirms previous qualitative findings, it raises questions for further exploration: at what point does the threat of exposure become an opportunity for prejudice-reducing intergroup contact?

The Northern Ireland conflict offers a uniquely data rich context for our research, but it also raises questions of generalizability. How do our findings extend to contexts with more than two competing ethnic groups? Fortunately, our empirical strategy, using the locations of ethnic structures instead of flawed population data, does not depend on the number of groups, but on the existence of pre-conflict structures belonging specifically to each ethnic community. As we note in the paper, our approach is compatible with various operational- 
izations of diversity, including the RQ measure and the Ethnolinguistic Fractionalization measure we use as a robustness check. Thus, our findings are not dependent on the specific operationalization of diversity in a two-group case. However, other formal-theoretic analysis has noted that the operationalization of diversity (polarization versus fractionalization, for instance) may matter in cases with more than three groups, given the differences in how these indices are computed (Esteban and Ray 2008). Our research opens avenues for an empirical investigation of this issue, assessing potential differences in diversity's effect, using alternative operationalizations in cases with more than two groups, absent the confounding flaws of population data from conflict zones. 


\section{References}

Adida, Claire, David Laitin, and Marie-Anne Valfort (2015). “"One Muslim is Enough!” Evidence from a Field Experiment in France." In: Annals of Economics and Statistics. Aktürk, Şener (2012). Regimes of ethnicity and nationhood in Germany, Russia, and Turkey. New York, NY: Cambridge University Press.

Allport, Gordon W. (1954). The Nature of Prejudice. Reading, MA: Addison-Wesley Publishing.

Balcells, Laia (2010). "Rivalry and Revenge: Violence against Civilians in Conventional Civil Wars." In: International Studies Quarterly 54.2, pp. 291-313.

- (2011). "Continuation of Politics by Two Means: Direct and Indirect Violence in Civil War." In: Journal of Conflict Resolution 55.3, pp. 397-422.

Balcells, Laia, Lesley-Ann Daniels, and Abel Escribà-Folch (2016). "The determinants of low-intensity intergroup violence: The case of Northern Ireland." In: Journal of Peace Research 53.1, pp. 33-48.

Balcells, Laia and Stathis N. Kalyvas (2014). "Does Warfare Matter? Severity, Duration, and Outcomes of Civil Wars." In: Journal of Conflict Resolution 58.8, pp. 1390-1418.

Bardon, Jonathan (1982). Belfast: An Illustrated History. Dundonald, Northern Ireland: The Blackstaff Press.

Boal, Fredrick W. In: ().

— (1972). "The urban residential sub-community - a conflict interpretation." In: Area 4.3.

- (1982). "Segregation and Mixing: Space and Residence in Belfast." In: Integration and Division: Geographical Perspectives on the Northern Ireland Problem. Ed. by Frederick W. Boal and J. Neville H. Douglas. New York, NY: Academic Press.

CAIN (2014). Conflict and Politics in Northern Ireland. University of Ulster. Derry/Londonderry, Northern Ireland.

Cikara, Mina, Vasiliki Fouka, and Marco Tabellini (2020). Hate crime increases with minoritized group rank. 
Coogan, Tim Pat (1993). The IRA. London: Harper Collins.

Costalli, Stefano and Francesco Niccolò Moro (2012). "Ethnicity and strategy in the Bosnian civil war: Explanations for the severity of violence in Bosnian municipalities." In: Journal of Peace Research 49.6, pp. 801-815.

Cunningham, Niall and Ian Gregory (2014). "Hard to miss, easy to blame? Peacelines, interfaces and political deaths in Belfast during the Troubles." In: Political Geography 40, pp. $64-78$.

Dinas, Elias et al. (2019). "Waking Up the Golden Dawn: Does Exposure to the Refugee Crisis Increase Support for Extreme-Right Parties?" In: Political Analysis 27.2, 244-254.

Doherty, Paul and Michael A. Poole (1997). "Ethnic residential segregation in Belfast, Northern Ireland, 1971-1991." In: Geographical Review 87.4.

Enos, Ryan D. (2014). "Causal effect of intergroup contact on exclusionary attitudes." In: Proceedings of the National Academy of Sciences 111.10.

Esteban, Joan and Debraj Ray (2008). "On the salience of ethnic conflict." In: American Economic Review 98.5, pp. 2185-2202.

Feldman, Allen (1991). Formations of Violence: The narrative of the body and political terror in Northern Ireland. The University of Chicago Press.

Census forms burned in Belfast streets (1971).

Fjelde, Hanne and Lisa Hultman (2014). "Weakening the Enemy: A Disaggregated Study of Violence against Civilians in Africa." In: Journal of Conflict Resolution 58.7, pp. 12301257.

Gallagher, James (1971). "Police will not be told." In: Irish Independent, p. 15.

Gladstone, Rick and Peter Robins (2021). "The Ghosts of Northern Ireland's Troubles are back. What's going on?" In: The New York Times.

Glaeser, Edward L (2005). "The political economy of hatred." In: Quarterly Journal of Economics 120.1, pp. 45-86. 
Griffiths, Hywel (1971). FLIGHT: A Report on Population Movement in Belfast during August, 1971. Belfast: Northern Ireland Community Relations Commission.

Hägerdal, Nils (2019). "Ethnic Cleansing and the Politics of Restraint: Violence and Coexistence in the Lebanese Civil War." In: Journal of Conflict Resolution 63.1, pp. 5984.

Hancock, Landon (1998). Northern Ireland: Troubles Brewing. Derry, UK: CAIN, University of Ulster.

Hewstone, Miles and Hermann Swart (2011). "Fifty-odd years of inter-group contact: From hypothesis to integrated theory." In: British Journal of Social Psychology 50, pp. 374386.

Hopkins, Daniel J. (2010). "Politicized Places: Explaining Where and When Immigrants Provoke Local Opposition." In: American Political Science Review 104.1, 40-60.

Irvine, Maurice (1991). Northern Ireland: Faith and Faction. New York, NY: Routledge. Jha, Saumitra (2013). "Trade, institutions, and ethnic tolerance: Evidence from South Asia." In: American Political Science Review 107.04, pp. 806-832.

Kalyvas, Stathis (2006). The Logic of Violence in Civil War. New York, NY: Cambridge University Press.

Kasara, Kimuli (2016). "Does Local Ethnic Segregation Lead to Violence?: Evidence from Kenya." In: Quarterly Journal of Political Science 11.4, pp. 441-470.

Klašnja, Marko and Natalija Novta (2014). "Segregation, Polarization, and Ethnic Conflict." In: Journal of Conflict Resolution.

Kopstein, Jeffrey S and Jason Wittenberg (2011). "Deadly communities: Local political milieus and the persecution of Jews in occupied Poland." In: Comparative Political Studies 44.3, pp. 259-283.

Lemmer, Gunnar and Ulrich Wagner (2015). "Can we really reduce ethnic prejudice outside the lab? A meta-analysis of direct and indirect contact interventions." In: European Journal of Social Psychology 45, pp. 151-168. 
Lowe, Matt (Forthcoming). Types of contact: a field experiment on collaborative and adversarial caste integration.

Loyle, Cyanne E, Christopher Sullivan, and Christian Davenport (2014). "The Northern Ireland Research Initiative: Data on the Troubles from 1968 to 1998." In: Conflict Management and Peace Science 31.1, pp. 94-106.

McGee, Caroline M. (2013). "A noble Church in the most Catholic quarter of a bitterly Protestant and Presbyterian city: The Church of the Most Holy Redeemer, Clonard, West Belfast'." In: Belfast: The Emerging City, 1850-1914. Ed. by Olwen Purdue. Dublin: Irish Academic Press.

McKittrick, David et al. (2001). Lost Lives: The stories of the men, women and children who died as a result of the Northern Ireland troubles. Random House.

Mesev, Victor, Peter Shirlow, and Joni Downs (2009). "The Geography of Conflict and Death in Belfast, Northern Ireland." In: Annals of the Association of American Geographers 99.5, pp. 893-903.

Montalvo, Jose G. and Marta Reynal-Querol (2010). "Ethnic Polarization and the Duration of Civil Wars." In: Economics of Governance 11.2, pp. 123-143.

Mousa, Salma (2020). "Building social cohesion between Christians and Muslims through soccer in post-ISIS Iraq." In: Science 369.6505, pp. 866-870. eprint: https://science. sciencemag.org/content/369/6505/866.full.pdf.

Mueller, Hannes, Dominic Rohner, and David Schönholzer (2019). The Peace Dividend of Distance: Violence as Interaction Across Space. unpublished working paper.

Newman, Benjamin J., Todd K. Hartman, and Charles S. Taber (2012). "Foreign Language Exposure, Cultural Threat, and Opposition to Immigration." In: Political Psychology 33.5, pp. 635-657. eprint: https://onlinelibrary.wiley.com/doi/pdf/10.1111/j . $1467-9221.2012 .00904 . x$. 
Newman, Benjamin J. and Yamil Velez (2014). "Group Size versus Change? Assessing Americans' Perception of Local Immigration." In: Political Research Quarterly 67.2, pp. 293303. eprint: https://doi.org/10.1177/1065912913517303.

Northern Ireland Statistics and Research Agency (2005). Urban-Rural Classification (2005). Online.

O’Connor, Tom (1971). "Paisley urges census action." In: Irish Press, p. 3.

O'Hearn, Denis (1983). "Catholic Grievances, Catholic Nationalism: A Comment." In: The British Journal of Sociology 34.3, pp. 438-445.

Pettigrew, Thomas F and Linda R Tropp (2008). "How does intergroup contact reduce prejudice? Meta-analytic tests of three mediators." In: European Journal of Social Psychology 38.6, pp. 922-934.

Posen, Barry R. (1993). "The Security Dilemma and Ethnic Conflict." In: Survival 35.1, pp. $27-47$.

Putnam, Robert D. (1994). Making Democracy Work: Civic Traditions in Modern Italy. Princeton, NJ: Princeton University Press.

- (2000). Bowling Alone: The Collapse and Revival of American Community. New York, NY: Simon and Schuster.

Rae, James R., Anna-Kaisa Newheiser, and Kristina R. Olson (2015). "Exposure to Racial Out-Groups and Implicit Race Bias in the United States." In: Social Psychological and Personality Science 6.5, pp. 535-543. eprint: https : //doi .org/10.1177/1948550614567357.

Schieferdecker, David and Hartmut Wessler (2017). "Bridging Segregation Via Media Exposure? Ingroup Identification, Outgroup Distance, and Low Direct Contact Reduce Outgroup Appearance in Media Repertoires." In: Journal of Communication 67.6, pp. 9931014. eprint: https://onlinelibrary.wiley.com/doi/pdf/10.1111/jcom.12338.

Schutte, Sebastian (2017). "Geographic determinants of indiscriminate violence in civil wars." In: Conflict Management and Peace Science 34.4, pp. 380-405.

Bombs blast in Belfast (1971). 
Tilly, Charles (1978). From Mobilization to Revolution. New York, NY: Random House.

Toft, Monica Duffy (2003). The Geography of Ethnic Violence. Princeton, NJ: Princeton University Press.

Varshney, Ashutosh (2001). "Ethnic Conflict and Civil Society: India and Beyond." In: World Politics 53.3, pp. 362-398.

Weidmann, Nils B. (2011). "Violence 'from above' or 'from below'? The Role of Ethnicity in Bosnia's Civil War." In: Journal of Politics 73.4, pp. 1178-1190.

Weidmann, Nils, Jan Ketil Rød, and Lars-Erik Cederman (2010). "Representing ethnic groups in space: A new dataset." In: Journal of Peace Research 47.4, pp. 491-499. 


\section{Appendix}
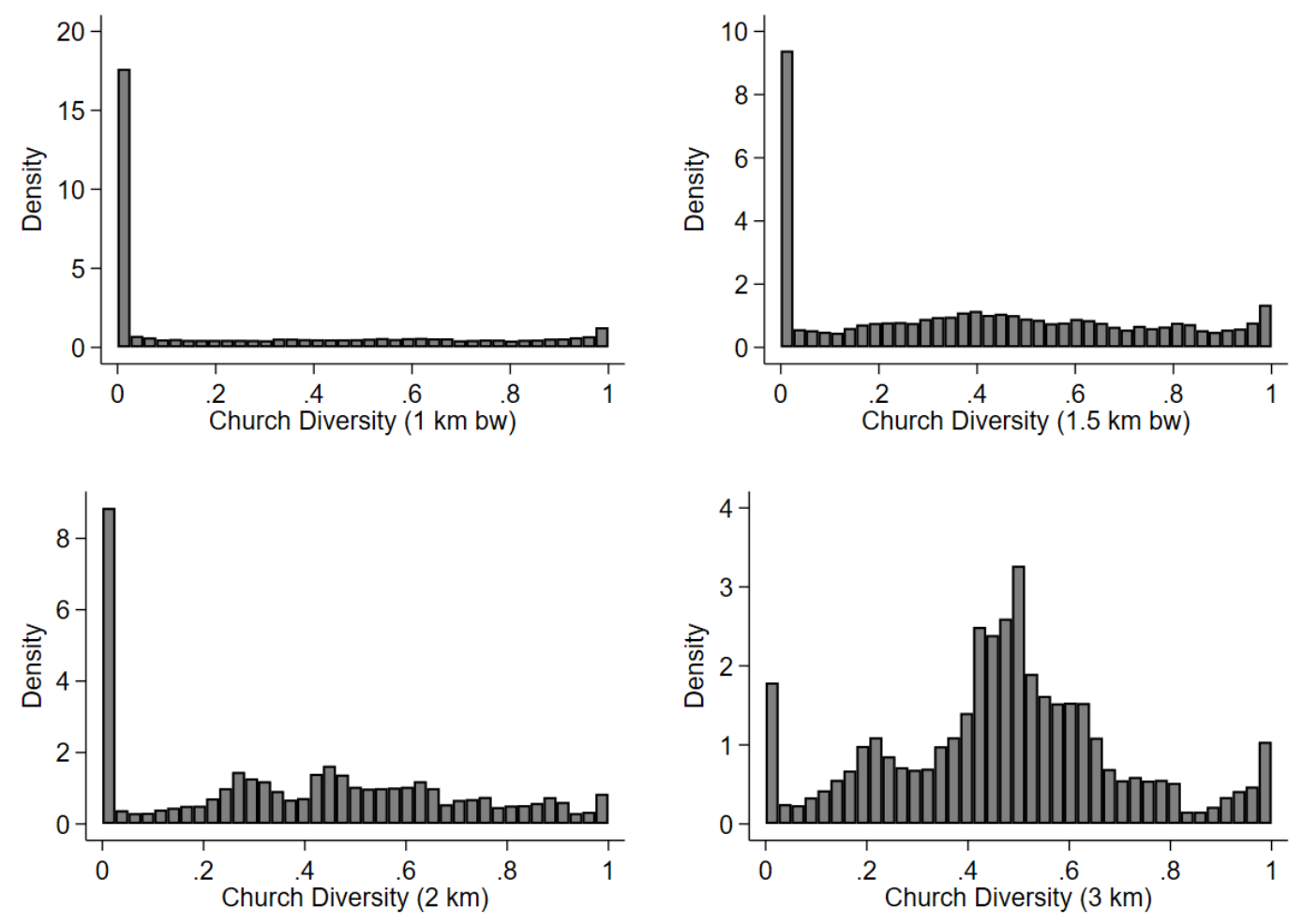

Figure A1: Histogram of church diversity variable at varying bandwidths. 
$[\mathrm{h} !]$

Table A1: Church Diversity calculated with Ethnolinguistic Fractionalization

\begin{tabular}{lccccc}
\hline & $(1)$ & $(2)$ & $(3)$ & $(4)$ & $(5)$ \\
Church diversity kernel bandwidth: & $1 \mathrm{~km}$ & $1 \mathrm{~km}$ & $1.5 \mathrm{~km}$ & $2 \mathrm{~km}$ & $3 \mathrm{~km}$ \\
\hline \multirow{2}{*}{ Church Diversity } & $1.279^{*}$ & 0.0273 & $7.696^{* * *}$ & $10.39^{* * *}$ & $13.43^{* * *}$ \\
& $(0.746)$ & $(1.945)$ & $(2.716)$ & $(3.254)$ & $(3.703)$ \\
Church Diversity Squared & & 2.535 & $-10.58^{* *}$ & $-13.45^{* *}$ & $-16.65^{* * *}$ \\
& & $(4.140)$ & $(4.611)$ & $(6.462)$ & $(6.229)$ \\
Observations & 5,386 & 5,386 & 5,451 & 5,451 & 5,451 \\
\hline
\end{tabular}

Notes: Results from Poisson estimations, with number of victims as the dependent variable, church diversity constructed at $1 \mathrm{~km}$ (column 1 as a linear term, column 2 quadratic), $1.5 \mathrm{~km}$ (column 3), $2 \mathrm{~km}$ (4) or $3 \mathrm{~km}$ (5) bandwidths. Regressions control for log distance to nearest Catholic church, log distance to nearest Protestant church, log population and three variables for proportion of households without hot water, without a bath or shower, and without an inside toilet. Coefficients for these distance, population and SES controls, as well as for the constant term, are not shown. Standard errors are clustered by 1993 ward boundaries, and significance levels are denoted at conventional levels ${ }^{* * *} \mathrm{p}<0.01,{ }^{* *} \mathrm{p}<0.05,{ }^{*} \mathrm{p}<0.1$. 


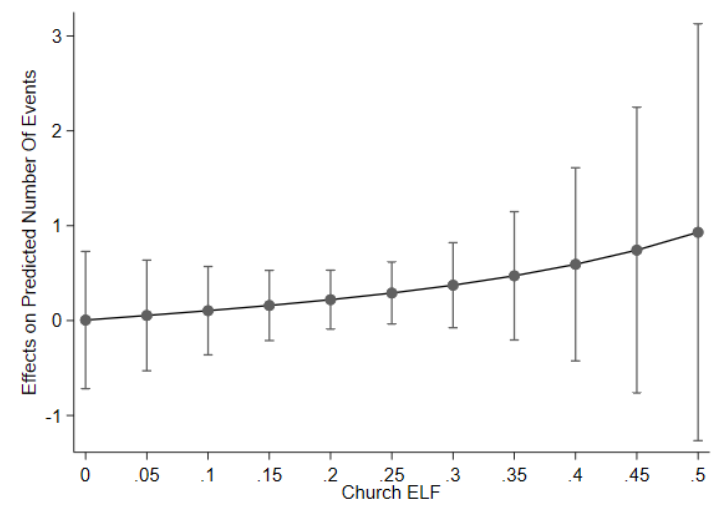

(a) $1 \mathrm{~km}$

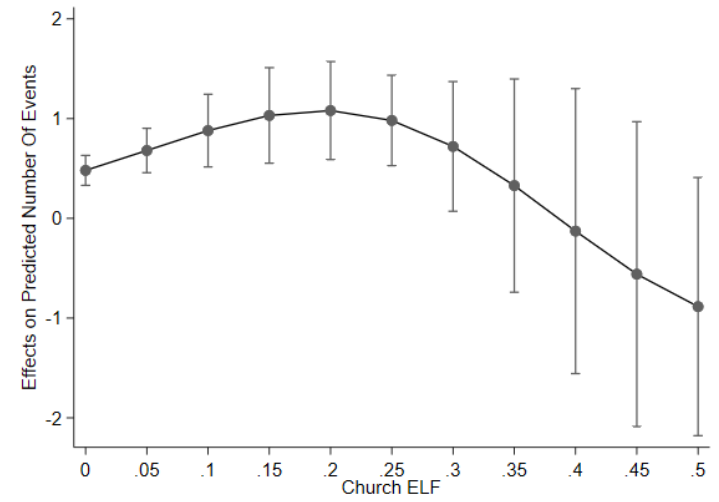

(c) $2 \mathrm{~km}$

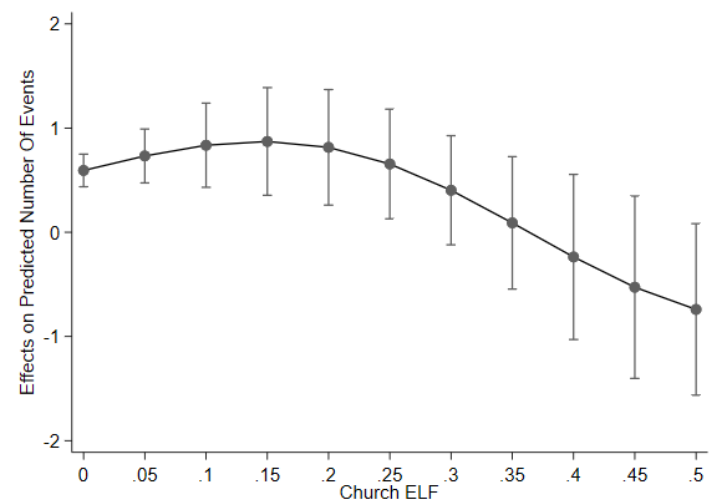

(b) $1.5 \mathrm{~km}$

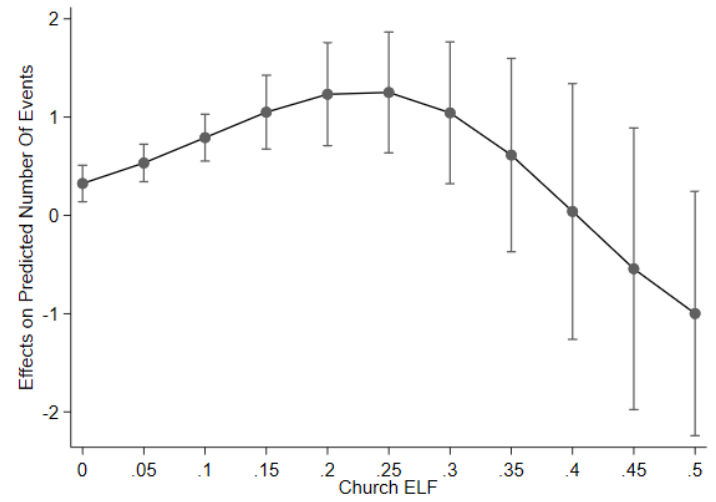

(d) $3 \mathrm{~km}$

Figure A2: Marginal Effects of Church Diversity on Violence, using ELF for Church Diversity construction 
$[\mathrm{h} !]$

Table A2: Poisson Estimates excluding Socioeconomic Controls

\begin{tabular}{lcccc}
\hline & $(1)$ & $(2)$ & $(3)$ & $(4)$ \\
Church diversity kernel bandwidth: & $1 \mathrm{~km}$ & $1.5 \mathrm{~km}$ & $2 \mathrm{~km}$ & $3 \mathrm{~km}$ \\
\hline \multirow{2}{*}{ Church Diversity } & $1.499^{*}$ & $4.306^{* * *}$ & $6.399^{* * *}$ & $5.410^{* * *}$ \\
& $(0.843)$ & $(1.209)$ & $(1.643)$ & $(1.697)$ \\
Church Diversity Squared & -1.191 & $-3.822^{* * *}$ & $-5.379^{* * *}$ & $-3.992^{* *}$ \\
& $(1.022)$ & $(1.259)$ & $(1.861)$ & $(1.556)$ \\
Observations & 7,931 & 8,196 & 8,255 & 8,258 \\
\hline
\end{tabular}

Notes: Results from Poisson estimations, with number of victims as the dependent variable, church diversity constructed at $1 \mathrm{~km}$ (column 1 as a linear term, column 2 quadratic), $1.5 \mathrm{~km}$ (column 3), $2 \mathrm{~km}$ (4) or $3 \mathrm{~km}$ (5) bandwidths. Regressions control for log distance to nearest Catholic church, log distance to nearest Protestant church, and log population, whose coefficients, as well as for the constant term, are not shown. Standard errors are clustered by 1993 ward boundaries, and significance levels are denoted at conventional levels ${ }^{* * *} \mathrm{p}<0.01,{ }^{* *} \mathrm{p}<0.05$, * $\mathrm{p}<0.1$. 


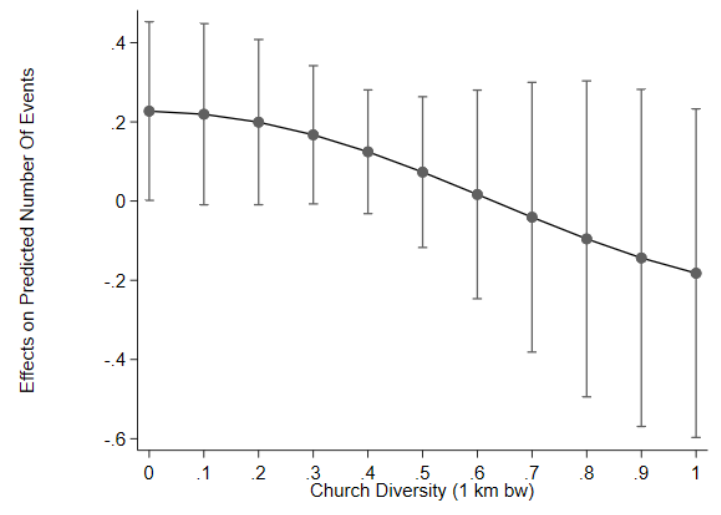

(a) $1 \mathrm{~km}$

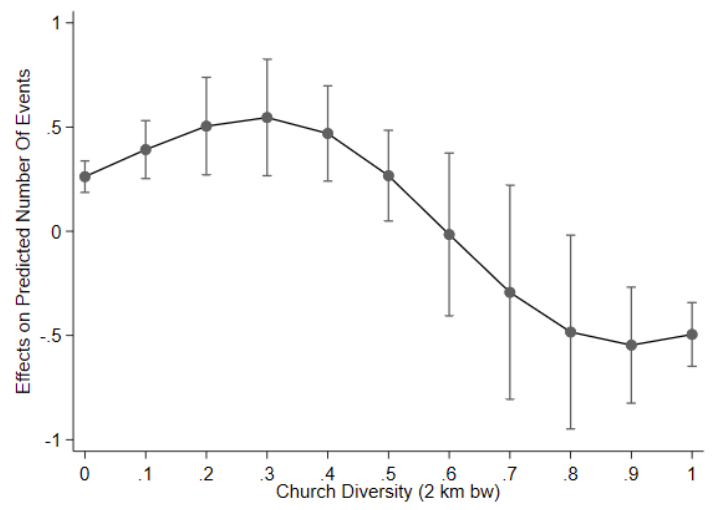

(c) $2 \mathrm{~km}$

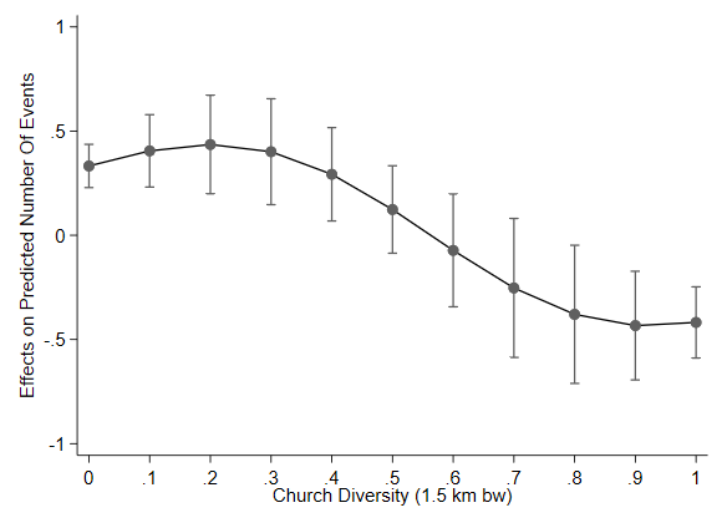

(b) $1.5 \mathrm{~km}$

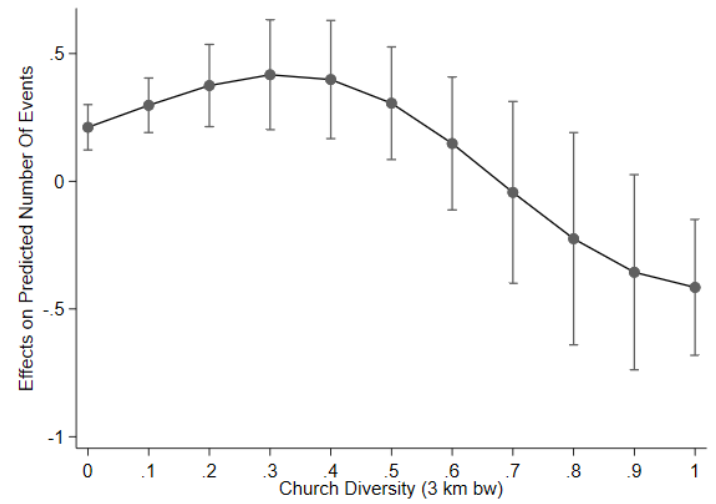

(d) $3 \mathrm{~km}$

Figure A3: Marginal Effects of Church Diversity on Violence, excluding Socioeconomic Controls 
$[\mathrm{h} !]$

Table A3: Negative Binomial Estimates

\begin{tabular}{lccccc}
\hline & $(1)$ & $(2)$ & $(3)$ & $(4)$ & $(5)$ \\
Church diversity kernel bandwidth: & $1 \mathrm{~km}$ & $1 \mathrm{~km}$ & $1.5 \mathrm{~km}$ & $2 \mathrm{~km}$ & $3 \mathrm{~km}$ \\
\hline \multirow{2}{*}{ Church Diversity } & 0.271 & -0.491 & $2.169^{*}$ & $4.017^{* * *}$ & $4.941^{* * *}$ \\
& $(0.328)$ & $(0.934)$ & $(1.143)$ & $(1.197)$ & $(1.722)$ \\
Church Diversity Squared & & 0.809 & -1.354 & $-2.308^{*}$ & $-2.620^{*}$ \\
& & $(1.021)$ & $(1.080)$ & $(1.241)$ & $(1.411)$ \\
Observations & 5,386 & 5,386 & 5,451 & 5,451 & 5,451 \\
\hline
\end{tabular}

Notes: Results from Negative Binomial estimations, with number of victims as the dependent variable, church diversity constructed at $1 \mathrm{~km}$ (column 1 as a linear term, column 2 quadratic), $1.5 \mathrm{~km}$ (column 3), $2 \mathrm{~km}$ (4) or $3 \mathrm{~km}$ (5) bandwidths. Regressions control for log distance to nearest Catholic church, log distance to nearest Protestant church, log population as well as three variables for proportion of households without hot water, without a bath or shower, and without an inside toilet. Coefficients for these distance, population and SES controls, as well as for the constant term, are not shown. Standard errors are clustered by 1993 ward boundaries, and significance levels are denoted at conventional levels ${ }^{* * *} \mathrm{p}<0.01,{ }^{* *} \mathrm{p}<0.05,{ }^{*} \mathrm{p}<0.1$. 


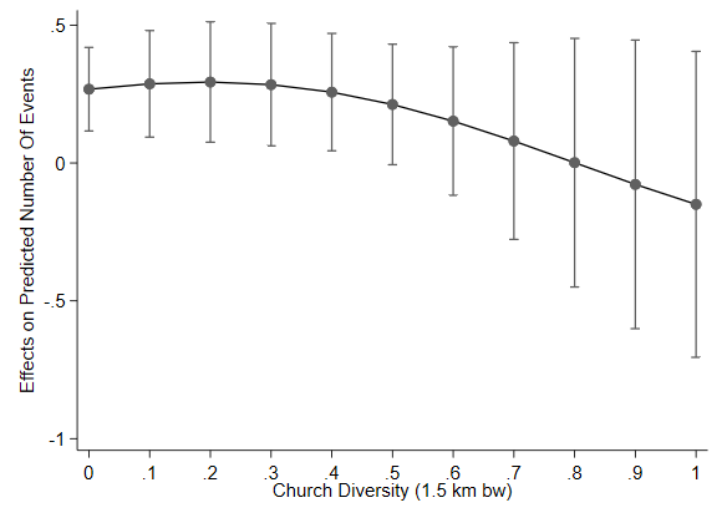

(a) $1.5 \mathrm{~km}$

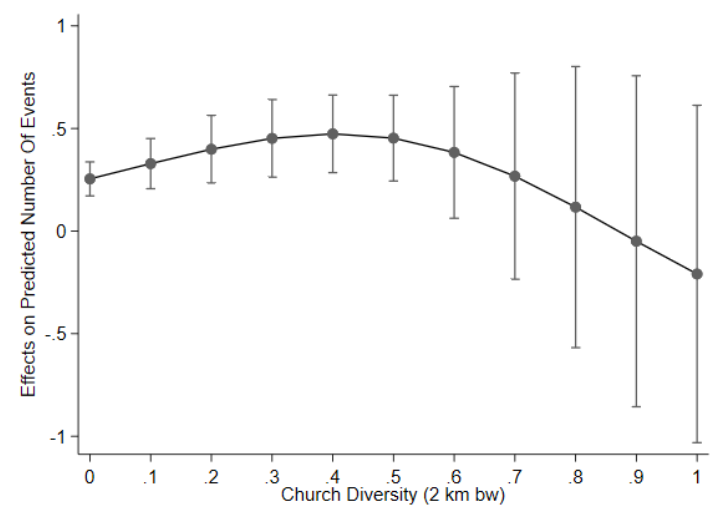

(b) $2 \mathrm{~km}$

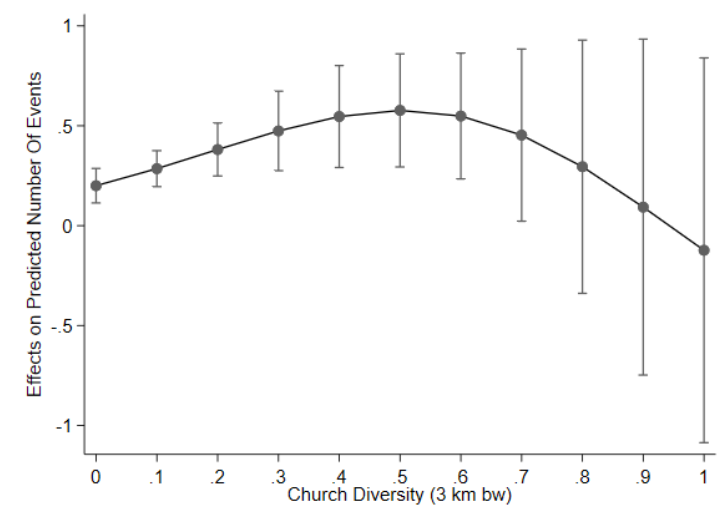

(c) $3 \mathrm{~km}$

Figure A4: Marginal Effects of Church Diversity on Violence using Negative Binomial 
Table A4: Excluding Later Deaths

\begin{tabular}{|c|c|c|c|}
\hline \multicolumn{4}{|l|}{$1.5 \mathrm{~km}$ bandwidth } \\
\hline & (1) & (2) & (3) \\
\hline & All & pre-1990 & pre-1980 \\
\hline \multirow[t]{2}{*}{ Church Diversity } & $3.848^{* * *}$ & $4.104^{* * *}$ & $4.744^{* * *}$ \\
\hline & $(1.358)$ & $(1.492)$ & (1.763) \\
\hline \multirow[t]{2}{*}{ Church Diversity Squared } & $-2.645^{* *}$ & $-2.860^{* *}$ & $-3.378^{* *}$ \\
\hline & (1.153) & $(1.204)$ & $(1.453))$ \\
\hline Observations & 5,451 & 5,451 & 5,451 \\
\hline \multicolumn{4}{|l|}{$2 \mathrm{~km}$ bandwidth } \\
\hline & (4) & (5) & (6) \\
\hline & All & pre-1990 & pre-1980 \\
\hline \multirow[t]{2}{*}{ Church Diversity } & $5.194^{* * *}$ & $5.253^{* * *}$ & $5.894^{* * *}$ \\
\hline & $(1.627)$ & (1.796) & $(2.123)$ \\
\hline \multirow{2}{*}{ Church Diversity Squared } & $-3.363^{* *}$ & $-3.329^{*}$ & $-4.921^{*}$ \\
\hline & $(1.616)$ & $(1.727)$ & $(2.017)$ \\
\hline Observations & 5,451 & 5,451 & 5,451 \\
\hline \multicolumn{4}{|l|}{$3 \mathrm{~km}$ bandwidth } \\
\hline \multirow[t]{2}{*}{ 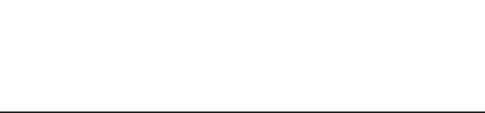 } & (6) & (7) & (8) \\
\hline & All & pre-1990 & pre-1980 \\
\hline \multirow[t]{2}{*}{ Church Diversity } & $6.717^{* * *}$ & $6.686^{* * *}$ & $9.547^{* * *}$ \\
\hline & $(1.852)$ & $(2.058)$ & $(2.633)$ \\
\hline \multirow[t]{2}{*}{ Church Diversity Squared } & $-4.164^{* * *}$ & $-4.122^{* *}$ & $-6.559 * * *$ \\
\hline & (1.557) & $(1.717)$ & (2.130) \\
\hline Observations & 5,451 & 5,451 & 5,451 \\
\hline
\end{tabular}

Notes: Results from a Poisson estimation, with number of victims as the dependent variable, church diversity constructed at $1.5 \mathrm{~km}, 2 \mathrm{~km}$ or $3 \mathrm{~km}$ bandwidths, excluding deaths after 1980 or after 1990 as indicated in column title. Regressions control for log distance to nearest Catholic

church, log distance to nearest Protestant church, log population and three variables for proportion of households without hot water, without a bath or shower, and without an inside toilet. Coefficients for these distance, population and SES controls, as well as for the constant term, are not shown. Standard errors are clustered by 1993 ward boundaries, and significance levels are denoted at conventional levels ${ }^{* * *} \mathrm{p}<0.01,{ }^{* *} \mathrm{p}<0.05,{ }^{*} \mathrm{p}<0.1$. 